\title{
Belowground interactive effects of elevated CO2, plant diversity and earthworms in grassland microcosms
}

Article

Accepted Version

Milcu, A., Paul, S. and Lukac, M. (2011) Belowground interactive effects of elevated $\mathrm{CO} 2$, plant diversity and earthworms in grassland microcosms. Basic and Applied Ecology, 12 (7). pp. 600-608. ISSN 1439-1791 doi: https://doi.org/10.1016/j.baae.2011.08.004 Available at https://centaur.reading.ac.uk/21815/

It is advisable to refer to the publisher's version if you intend to cite from the work. See Guidance on citing.

To link to this article DOI: http://dx.doi.org/10.1016/j.baae.2011.08.004

Publisher: Elsevier

All outputs in CentAUR are protected by Intellectual Property Rights law, including copyright law. Copyright and IPR is retained by the creators or other copyright holders. Terms and conditions for use of this material are defined in the End User Agreement.

www.reading.ac.uk/centaur 
Central Archive at the University of Reading

Reading's research outputs online 
Number of text pages: 25

Number of tables: 1

Number of figures: 2

Appendixes: 1

Belowground interactive effects of elevated $\mathrm{CO}_{2}$, plant diversity and earthworms in model grasslands

$14{ }^{1}$ NERC Centre for Population Biology, Division of Biology, Imperial College London,

15 Silwood Park, Ascot SL5 7PY, UK

$16{ }^{2}$ School of Agriculture, Policy and Development, University of Reading, Whiteknights

17 Campus, Reading, RG6 6AR, UK

*Corresponding author:

Alexandru Milcu - NERC Centre for Population Biology, Imperial College London, Silwood Park, Ascot SL5 7PY, UK, e-mail: a.milcu@imperial.ac.uk 


\section{ABSTRACT}

26 The potential interactive effects of future atmospheric $\mathrm{CO}_{2}$ concentrations and plant diversity

27 loss on the functioning of belowground systems are still poorly understood. Using a 28 microcosm greenhouse approach with assembled grassland plant communities of different 29 diversity (1, 4 and 8 species), we explored the interactive effects between plant species 30 richness and elevated $\mathrm{CO}_{2}$ (ambient and +200 p.p.m.v. $\mathrm{CO}_{2}$ ) on earthworms and microbial biomass. We hypothesised that the beneficial effect of increasing plant species richness on earthworm performance and microbial biomass will be modified by elevated $\mathrm{CO}_{2}$ through impacts on belowground organic matter inputs, soil water availability and nitrogen

34 availability. We found higher earthworm biomass in eight species mixtures under elevated $35 \mathrm{CO}_{2}$, and higher microbial biomass under elevated $\mathrm{CO}_{2}$ in four and eight species mixtures if earthworms were present. The results suggest that plant driven changes in belowground organic matter inputs, soil water availability and nitrogen availability explain the interactive effects of $\mathrm{CO}_{2}$ and plant diversity on the belowground compartment. The interacting mechanisms by which elevated $\mathrm{CO}_{2}$ modified the impact of plant diversity on earthworms and microorganisms are discussed.

Keywords: Climate change; Species richness; Above-belowground interactions; Water availability; Soil N; Lumbricus terrestris 
Introduction

50 Understanding of the relationship between biodiversity, climate change and the ecosystem services upon which we are heavily reliant emerged as a critical issue in the face of increasing human-induced environmental change (Millennium Ecosystem Assessment 2005). Whilst much attention has been devoted to separately studying the impacts of climate change and biodiversity loss, considerably less is known about their interactive effects on ecosystems and the services they provide (Balvanera, Pfisterer, Buchmann, He, Nakashizuka et al. 2006). Studies which include the effects of climate change factors on the functioning of the belowground compartment are even fewer and by and large highlight the considerable lack of knowledge in this area (Chung, Zak, Reich \& Ellsworth 2007, Kardol, Cregger, Campany \& Classen. 2010). Since the biological functioning and the species composition of the belowground compartment is dependent on organic matter inputs from photosynthesising plants, the understanding of the links between producer and decomposer subsystems is essential for predicting of ecosystem-level responses to global change (Wardle 2002). surface (Henwood 1998), highlighting their importance as model systems used for investigating the consequences of biodiversity loss (Roscher, Temperton, Scherer-Lorenzen, Schmitz, Schumacher et al. 2005, Tilman, Reich \& Knops 2006) or elevated $\mathrm{CO}_{2}$ (Niklaus,

67 Alphei, Kampichler, Kandeler, Körner et al. 2007, Reich 2009). Reich, Knops, Tilman, Craine, Ellsworth et al. (2001) showed that plant diversity interacts with elevated $\mathrm{CO}_{2}$ and

69 nitrogen availability to modify ecosystem functioning. Furthermore, elevated atmospheric $70 \mathrm{CO}_{2}$ concentrations usually reduce stomatal density and conductance (Woodward \& Bazzaz 71 1988; Tricker, Trewin, Kull, Clarkson, Eensalu et al. 2005) which may result in increased soil moisture by reducing evapotranspiratory loss of water (Morgan et al. 2001; Nelson, Morgan, Lecain, Mosier, Milchunas et al. 2004) under elevated levels of $\mathrm{CO}_{2}$. Although both $\mathrm{CO}_{2}$ and 
plant diversity loss have been shown to impact the decomposer functioning through changes

in the quality and quantity of organic matter inputs and impacts on soil moisture and nutrient availability, we have a limited understanding of their combined effects on the decomposer functioning (Niklaus et al. 2007) despite their important role in biogeochemical cycling, plant performance and soil C storage (Bardgett 2005).

Both earthworms and microorganisms are key decomposer groups sensitive to changes in the aboveground inputs, as well as soil water and nutrient regimes. Currently we have only a limited mechanistic understanding of the interactive effects of elevated $\mathrm{CO}_{2}$ and plant diversity loss on their performance. The few studies which report effects of elevated $\mathrm{CO}_{2}$ on earthworms predominantly measure their response in terms of activity, indicating increased activity with increasing levels of $\mathrm{CO}_{2}$ (Yeates, Tate \& Newton 1997, Arnone \& Zaller 1997; Zaller \& Arnone 1999c). However, an observation of community biomass and composition by Zaller \& Arnone (1999c) found no effects of elevated $\mathrm{CO}_{2}$. Available data also show that increasing plant species diversity (Zaller \& Arnone 1999b; Speh, Josh, Schmid, Alphei \& Körner 2000; Niklaus et al. 2007) has a positive effect on earthworm biomass and activity, but depends on species-specific relationships with earthworms (Zaller \& Arnone 1999c; Milcu, Partsch, Langel \& Scheu 2006). Milcu et al. (2006) suggested that changes in the quality rather than quantity of plant inputs associated with changes in species diversity affect earthworm performance. The consequences of elevated $\mathrm{CO}_{2}$ on microorganisms are still unclear due to insufficient data to predict how microbial biomass and functioning change as atmospheric $\mathrm{CO}_{2}$ concentration continues to rise (Zak et al 2000, Bardgett, Freeman \& Ostle YEAR). The effect of diversity loss on soil microorganisms is somewhat clearer with recent publications pointing out the positive relationship between plant diversity and the functioning and biomass of microbial communities (Eisenhauer et al 2009). 
The scope for interacting effects of diversity loss and elevated $\mathrm{CO}_{2}$ on soil organisms

100 is clearly large. Climatic change is likely to both directly and indirectly (via plant responses)

101 affect soil biota, with associated consequences for ecosystem functioning. In this study we

102 explored the interaction between plant species richness, elevated $\mathrm{CO}_{2}$ and the presence of

103 earthworms and its effects on the belowground compartment of model grassland, using a

104 microcosm greenhouse experiment. Our overarching hypothesis is that the frequently observed beneficial effects of increasing the richness of plant species on earthworm performance and microbial biomass will be altered by elevated $\mathrm{CO}_{2}$, through changes in belowground organic matter inputs and altered soil water and nitrogen availability.

\section{Materials and methods}

110 Experimental set up

111 Experimental grassland communities of varied plant species richness (1, 4 and 8 species)

112 were established in cylindrical microcosms made of PVC tubes, $10.3 \mathrm{~cm}$ in diameter and 25

$113 \mathrm{~cm}$ in height. The microcosms were sealed at the bottom with $0.5 \mathrm{~mm}^{2}$ mesh, and a layer of 114 sand $(0.25 \mathrm{~kg})$ was added to the bottom of the microcosms to ensure efficient drainage. The 115 sand was topped by $1.6 \mathrm{~kg}$ of sieved soil ( $1 \mathrm{~cm}$ diameter sieve) taken from the A horizon of a 116 mesotrophic grassland (MG6 - Lolium perene - Cynosurus cristatus; Rodwell 1998) in

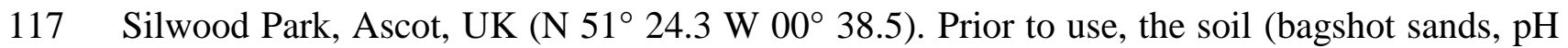

118 5.35) was homogenized and defaunated by freezing at $-22^{\circ} \mathrm{C}$ for two weeks (Huhta, Wright \& 119 Coleman 1989). Subsequently, the soil was watered intermittently over a 12 day period with 120 deionised water to remove excess nutrients released by the perturbation.

121 The microcosms were planted out with eight seedlings $(\sim 5 \mathrm{~cm}$ height $)$ pre122 germinated in John Innes compost from a species pool of 37 grassland species (Appendix 1).

123 The microcosms were assigned to eight air-conditioned chambers $(100 \mathrm{~cm} \times 100 \mathrm{~cm} \times 53.5$ 
$\mathrm{cm})$ located in a greenhouse. An elevated atmospheric $\mathrm{CO}_{2}$ treatment of $600 \mathrm{ppm}$ simulating the average prediction for 2100 (IPCC 2007) was applied to four of the chambers, with the other four receiving air with ambient concentration of $\sim 400 \mathrm{ppm}$.

The earthworm treatment (EW) was established by adding one Lumbricus terrestris $\mathrm{L}$. $(4.9774 \pm 0.067 \mathrm{~g} \mathrm{FW})$ to one set of the microcosms in each chamber. L. terrestris was chosen as a typical representative colonising the grassland type (MG6) from which the soil was extracted. As L. terrestris is an anecic litter feeding species, $3 \mathrm{~g}$ DW of Dactylis glomerata litter (cut into $3 \mathrm{~cm}$ pieces) was placed onto the soil surface in each microcosm. No additional litter entered the microcosms as any plant litter originating from the aboveground biomass was removed weekly. Each growth chamber thus contained 36 microcosms: two replicates of each species mixture, one containing a L. terrestris individual (EW) and one control (NW). The resulting total of 288 microcosms ( 3 plant diversity levels $\times 6$ replicates/diversity level $\times$ 2 earthworm treatments $\times 2 \mathrm{CO}_{2}$ levels $\times 4$ replicates per $\mathrm{CO}_{2}$ level) were fitted with $15 \mathrm{~cm}$ high cylindrical transparent plastic guards at the top of each microcosm to contain the earthworms in the microcosms. The greenhouse was lit naturally, but also received additional

139 light for 8 hours a day via 400 Watt overhead 'POOT' lamps. Identical environmental 140 conditions were maintained in all chambers, apart from the 4 chambers where atmospheric

$141 \mathrm{CO}_{2}$ was maintained at 600ppm for 8 hours during the photosynthetically active part of the

142 day. Air humidity, air temperature and $\mathrm{CO}_{2}$ levels of each chamber were monitored 143 continuously. The microcosms were watered every 3 days, initially with $30 \mathrm{ml}$ of deionised 144 water, increasing to $60 \mathrm{ml}, 80 \mathrm{ml}$ and then $120 \mathrm{ml}$ over the course of the experiment to account 145 for increasing water use by growing plants. The positions of the microcosms within the 146 growth chambers were randomised every 14 days. 
149 A pool of 37 South-East England mesotrophic acid grassland plant species belonging to three

150 functional groups (grasses, herbs and legumes) was used to produce a total of 18 different

151 species mixtures (see Appendix A) using independent random draws with replacement (i.e.

152 species mixtures were created by randomly selecting species from the species pool with all

153 species being available for to be drawn for any species mixture). The established gradient of

154 species diversity (1, 4 and 8) had 6 replicates per diversity level. Any sampling effects were

155 reduced by using species pool much larger than the maximum diversity level (Aarssen 1997).

\section{Sampling and analytical procedures}

158 The experiment has been harvested after four months of $\mathrm{CO}_{2}$ exposure when the majority of

159 plants showed signs of senescence. Immediately prior to destructive sampling, the soil

160 moisture level of each microcosm was measured (ThetaProbe Soil Moisture Sensor - ML2x,

161 Delta-T Products). Soil C/N content was analysed using a CNS elemental analyser (Thermo

162 Scientific FlashEA 1112 series). Earthworms were hand collected during the final harvest,

163 washed, dried for 1 min on filter paper and weighed. A sub-sample of soil was sieved to

164 remove any roots ( $2 \mathrm{~mm}$ dia.) and stored at $4^{\circ} \mathrm{C}$. After 2 weeks the soil was used to assess the microbial biomass using the substrate induced respiration (SIR) method (Anderson and Domsch, 1978) using electrolytic $\mathrm{O}_{2}$ microcompensation apparatus (Scheu 1992). The microbial respiratory response to the addition of glucose was measured at 30-minute intervals

168 for $24 \mathrm{~h}$ at $22^{\circ} \mathrm{C}$. Sufficient amount of glucose in solution was added to the substrate in order 169 to saturate the catabolic activity of microorganisms (4 mg glucose per $1 \mathrm{~g}$ of soil dry weight).

170 The maximum initial respiratory response (MIRR [ $\mu \mathrm{g} \mathrm{O} 2 * \mathrm{~h}-1 * \mathrm{~g}$ soil dw-1]) was calculated 171 as the average of the lowest three readings within the first $11 \mathrm{~h}$ and microbial biomass $\left(\mathrm{C}_{\mathrm{mic}}\right.$

$172\left[\mu \mathrm{g} \mathrm{C}_{\text {mic }}{ }^{\mathrm{g}} \mathrm{g}\right.$ soil $\left.\mathrm{dw}-1\right]$ ) was calculated as MIRR*38*0.7 (Anderson \& Domsch 1978). 
Statistical analysis

175 Mixed effects models, as implemented in the R Statistical package (lme function, $\mathrm{R}$ version 2.10.1), was used to analyse the fixed effects of $\mathrm{CO}_{2}\left(\mathrm{CO}_{2}\right)$, earthworm presence (EW), plant

177 species richness (SR) and their interactions on earthworm biomass, microbial biomass, soil

178 moisture and soil $\mathrm{N}$ and $\mathrm{C} / \mathrm{N}$ ratio. The random-effects of the maximal model, fit by

179 maximum likelihood, had a microcosm within chamber random structure to account for the 180 nested design [model <-lme $\left(\mathrm{y} \sim \mathrm{CO}_{2} * \mathrm{EW} * \mathrm{SR}\right.$, random $=\sim 1 \mid$ chamber $/$ microcosmID $)$,

181 where y indicates the response variable, chamber represents the eight growth chambers at

182 which the $\mathrm{CO}_{2}$ treatment has been applied and microcosmID represents the individual

183 microcosms]. Minimum adequate models were achieved by sequentially excluding non-

184 significant terms (starting with highest-order interactions) and comparing each model with its 185 predecessor using Akaike information criterion (Crawley 2007). Tukey's HSD posthoc test

186 was used to perform pairwise comparison of treatments with more than two levels. Several 187 continuous explanatory variables such as plant biomass (shoot, root, total), soil moisture and

188 soil $\mathrm{N}$ content were tested as covariables in the models for identifying potential mechanisms.

189 We used Statistica 8 package (StatSoft Inc) for graphical presentation of data.

190

\section{Results}

192 Earthworm body weight. In total, $81 \%$ of the 144 Lumbricus terrestris used were retrieved at

193 the end of the experiment and on average, their biomass decreased by $32 \%$. Neither the $\mathrm{CO}_{2}$

194 nor plant species richness treatments had a significant effect on earthworm biomass (Table 1).

195 They did, however, have a significant interactive effect $\left(\mathrm{CO}_{2} \times \mathrm{SR}\right.$; Table 2$)$ with earthworms

196 exhibiting lower biomass in the eight species mixtures at ambient (-37.8\%) than at elevated

$197 \mathrm{CO}_{2}(-29.5 \%)$ (Fig. 1a). 
198 Soil N. Soil nitrogen content at the end of the experiment was not affected by the $\mathrm{CO}_{2}$ treatment alone or by the presence of earthworms (Table 1). Increasing plant species richness led to significantly lower soil $\mathrm{N}$ (Table 1), with the lowest $\mathrm{N}$ concentration in the eight species mixtures $(0.13 \% \mathrm{~N})$ compared to one and four species mixtures $(0.14 \% \mathrm{~N})$.

202 Soil C/N ratio. Increasing plant diversity led to significantly higher C/N ratio (Fig. 1b).

203 Furthermore, the $\mathrm{C} / \mathrm{N}$ ratio was affected by the interaction between $\mathrm{CO}_{2}$ and earthworms $204\left(\mathrm{CO}_{2} \times \mathrm{EW}\right)$ with the lowest $\mathrm{C} / \mathrm{N}$ ratio in the presence of legumes under ambient $\mathrm{CO}_{2}$ conditions.

Soil moisture content. Elevated $\mathrm{CO}_{2}$ increased the soil moisture measured at the end of the experiment from $25.3 \%$ in the ambient $\mathrm{CO}_{2}$ to $29.3 \%$. Increasing plant species diversity led to significantly lower soil moisture in the four $(26.1 \%)$ and eight $(25.9 \%)$ species richness compared to monocultures $(30.1 \%$, Table 1$)$. Soil moisture was also affected by the interaction between $\mathrm{CO}_{2}$ concentration and the presence of earthworms $\left(\mathrm{CO}_{2} \times \mathrm{EW}\right.$; Table 1 and Figure 1c ), with significantly less available soil water in the earthworm treatment and

212 with the lowest amount of available soil water content at ambient $\mathrm{CO}_{2}$ in the presence of 213 earthworms (Tukey HSD <0.05).

214 Microbial biomass. Elevated $\mathrm{CO}_{2}$ marginally increased microbial biomass (+6.2\%) (Table 1).

215 Plant species richness also affected the microbial biomass, with significantly higher biomass

216 in the four species richness $\left(226.0 \mathrm{mg} \mathrm{Cmic} \mathrm{g}^{-1}\right.$ soil dry weight) compared to monocultures

217 (208.2 $\mathrm{mg} \mathrm{Cmic} \mathrm{g}^{-1}$ soil dry weight, Tukey HSD <0.05), with the eight species mixtures

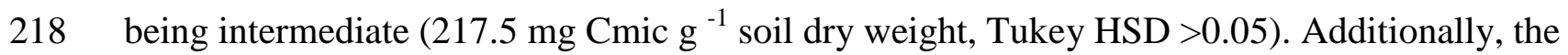

$219 \mathrm{CO}_{2}$ treatment, earthworm presence and plant species richness had an interactive effect $\left(\mathrm{CO}_{2}\right.$

$220 \times \mathrm{EW} \times \mathrm{SR}$; Table 2, Fig. 2) on the microbial biomass; under elevated $\mathrm{CO}_{2}$ only four and

221 eight species mixtures increased microbial biomass (Tukeys HSD <0.05) compared to 
monocultures if earthworms were present, while in the absence of earthworms microbial biomass was higher in the monocultures (Fig. 2).

\section{Discussion}

Despite their small scale and somewhat artificial nature, microcosm experiments have a good track record of providing an indication of processes and mechanisms directing ecosystem functioning at much larger scales (Benton, Solan, Travis \& Sait 2007). Given that all microcosms were constructed by using homogenised soil with standardised plant litter and no additional litter entered the soil, we contend that the observed effects of elevated $\mathrm{CO}_{2}$ were occurring through the rhizosphere. Although the experiment discussed in this paper lasted only for the equivalent of one vegetative season, the observations show several interactive effects of elevated $\mathrm{CO}_{2}$, earthworm presence and plant diversity on the functioning of the belowground compartment of a model temperate grassland.

\section{Earthworms}

It is widely accepted that the main drivers through which elevated $\mathrm{CO}_{2}$ will affect soil organisms are soil moisture (Niklaus et al. 2007) and plant derived organic matter inputs such as litter and rhizodeposition (O’Neill 1994, Meehan et al. 2010). Changes in both quantity and quality of soil organic matter inputs have been shown to change with increasing plant diversity, due to alterations in the amount and chemical composition of organic matter entering the soil. This may potentially have beneficial effects on the earthworm community (Edwards 1996; Milcu, Partsch, Scherber, Weisser \& Scheu 2008) though the relationship between plant species diversity and earthworm performance is unlikely to be straightforward with idiosyncratic effects often reported (Wardle, Bonner, Barker, Yeates, Nicholson et al. 1999; Eisenhower, Milcu, Sabais, Bessler, Weigelt et al. 2009). We observed higher 
247 earthworm biomass in microcosms with higher plant diversity (8 species), but only under

248 elevated $\mathrm{CO}_{2}$ treatment. However, since soil moisture, plant shoot, root and total biomass,

249 when used as potential covariables in the statistical model, did not render the $\mathrm{CO}_{2} \times \mathrm{SR}$

250 interaction non-significant, we contend that the increase in earthworm biomass under

251 elevated $\mathrm{CO}_{2}$ is not a result of changes in soil moisture or plant biomass. As no aboveground

252 inputs entered the system, the greater earthworm biomass could only have resulted from

253 additional belowground inputs. Elevated $\mathrm{CO}_{2}$ is known to generally enhance $\mathrm{N}$

254 rhizodeposition (Schultze \& Merbach 2008) and $\mathrm{N}_{2}$ fixation in legumes (Stephanie,

255 Fischinger, Hristozkova, Mainassara \& Schultze 2009) leading to increased total

256 belowground $\mathrm{N}$ transport. This likely explains the higher biomass of L. terrestris, an anecic

257 litter feeding species which has been previously shown to be closely linked to $\mathrm{N}$ availability

258 (Milcu et al. 2008). Interestingly, the lowest biomass of earthworms was observed at the

259 highest plant diversity level under ambient $\mathrm{CO}_{2}$. This is in contradiction with existing

260 literature which documents positive or idiosyncratic (Hedlund, Santa Regina, Van Der

261 Putten, Lepš, Diaz et al. 2003; Eisenhauer et al. 2009), but no detrimental effects of

262 increasing plant diversity on earthworm performance. The observed decrease in earthworm

263 biomass was likely caused by the high competition for $\mathrm{N}$ between plants and earthworms as

264 documented by the lower soil $\mathrm{N}$ and higher $\mathrm{C} / \mathrm{N}$ ratio in the eight species diversity mixtures

265 in an already low-N soil $(0.13 \% \mathrm{~N})$ (Fig. $1 \mathrm{~b})$. Indeed fitting the $\mathrm{C} / \mathrm{N}$ ratio in the model

266 renders the $\mathrm{CO}_{2} \times \mathrm{SR}$ interaction non-significant $(\mathrm{P}>0.05)$ and increases the fitness of the

267 model as estimated by the AIC.

Microbial biomass

270 Like earthworms, soil microorganisms are often found to respond to elevated 
$271 \mathrm{CO}_{2}$ by changing their community composition, overall biomass and activity (De Graaff,

272 Mavan Groenigen, Six, Hungate \& Van Kessel 2006; Blagodatskaya, Blagodatsky,

273 Dorodnikov \& Kuzyakov 2010). The magnitude and the sign of the effect of elevated $\mathrm{CO}_{2}$ on

274 microorganisms is not very clear, with no effects (Holmes et al 2006), detrimental (Hungate

275 et al. 1996) or idiosyncratic responses having been documented (Zak, Pregitzer, King \&

276 Holmes 2000; Kanerva, Palojärvi, Rämö \& Manninen. 2008). Here we only found a

277 marginally increased microbial carbon biomass $(\mathrm{Cmic})$ in the elevated $\mathrm{CO}_{2}$. Changes in litter

278 inputs, root biomass and production, soil moisture and rhizodeposition have been previously

279 identified to affect microbial biomass under elevated $\mathrm{CO}_{2}(\mathrm{Zak} 2000)$. However, whilst we

280 could not identify the exact mechanism, it is worth noting that this increase was mediated by

281 belowground effects of elevated $\mathrm{CO}_{2}$ as no aboveground plant litter entered the soil.

282 Moreover, we found significant changes in response to plant diversity. Higher Cmic at higher

283 plant diversity levels have recently been reported in a 7 year experiment (Eisenhauer et al.

284 2009). In our microcosms, we found the eight and four plant species mixtures to have higher

285 Cmic than the monocultures. However, contrary to our expectations, the highest biomass was

286 found in the four and not in the eight plant species mixtures. Higher $\mathrm{C}_{\text {mic }}$ at intermediate plant

287 diversity levels have been previously found in early stages of experiments manipulating

288 diversity as the effects of plants on the $\mathrm{C}_{\text {mic }}$ increased with time (Eisenhauer et al. 2009).

289 The presence of animal ecosystem engineers such as anecic earthworms also affects

290 the functioning of the belowground systems and microbial biomass has been noted to

291 increase due to accelerated incorporation of nutrient rich litter into the soil. Sheehan, Kirwan,

292 Connolly \& Bolger (2008) suggested that the positive effect of anecic species on microbial

293 biomass was greatest with increased food supply. We found that microbial biomass varied

294 with the presence of earthworms, plant species richness and $\mathrm{CO}_{2}$ level; higher microbial

295 biomass was found under elevated $\mathrm{CO}_{2}$ at higher plant diversity levels when earthworms 
were present, but also at the lower diversity level in the absence of earthworms. Given the inconclusiveness in observed effects, we could not identify the exact mechanism behind this interaction as none of the measured covariates (root biomass, total plant biomass, soil moisture or soil $\mathrm{N}$ content) affected the significance level of the interaction. This highlights

300 the complexity of belowground $\mathrm{C}$ fluxes, it is possible that a longer-term experiment might

301 be able to uncover such a mechanism by allowing the systems to stabilise and transient effects to lose their influence.

\section{Soil moisture}

305 Water availability frequently limits the functioning of the detritivore system (Swift, Heal \&

306 Anderson 1979; Austin 2002) with many soil decomposers migrating into deeper soil layers

307 or to entering a dormant stage under water stress, with consequences for the functioning of

308 the ecosystems. Water availability is essential for normal earthworm physiology due to their

309 cutaneous mode of respiration and for maintaining their coelomic hydrostatic pressure at

310 levels that allow locomotion (Lavelle 1988). Although highly dependent on soil water,

311 earthworm activities (e.g. burrowing, casting, midden formation) can affect the soil water

312 dynamics in a feedback loop through effects on soil physical properties. The mechanisms

313 include changes in soil porosity and stability of organomineral aggregates. By burrowing and

314 by the creation of organomineral casts, earthworms are generally thought to exert a beneficial

315 influence on soil water availability through increased water infiltration and by improving soil

316 water holding capacity (Edwards 2004). However, negative effects of earthworm activity on

317 soil water retention have also been reported (Blouin, Lavelle \& Laffray 2007) and there is

318 increasing evidence that elevated $\mathrm{CO}_{2}$ affects belowground communities also through

319 improved plant and soil water status due to reduced evapotranspiration via reduced leaf

320 conductance (Niklas et al 2007). This could play an important role in the functioning of the 
ecosystems particularly in conditions of water shortage when burrows increases water drainage and evaporative water loss. Our results are in line with the findings of Blouin et al. (2007), showing a significant decrease in soil moisture content in the presence of L. terrestris via preferential water flow through the vertical burrows which can account to up to $10 \%$ of the water flow (Edwards, Shipitalo, Owens \& Norton 1989). Given that in our experiment the soil water content was reduced by earthworms in both $\mathrm{CO}_{2}$ treatments, but that a smaller reduction was observed under to elevated $\mathrm{CO}_{2}$ (Fig. 1c), this suggests that both reduced soil water retention and increased water use efficiency (Wullschleger, Tschaplinski \& Norby 2002) contribute to the observed effects. However, it might not be possible to extrapolate our this finding to filed conditions due to differences in drainage and mater movement between microcosms and undisturbed soil profile. Our observations indicate that deep vertical macropores created by anecic eartworms may modify the effect of elevated $\mathrm{CO} 2$ on soil water availability, the mechanism behind this interaction remains to be verified in the field.

\section{Soil nitrogen}

336 In an extensive meta-analysis considering the effects of elevated $\mathrm{CO}_{2}$ on nutrient cycling De Graaff et al. (2006) found no effects on N mineralisation rates, but documented increased soil $\mathrm{C}$ inputs leading to increased soil $\mathrm{C} / \mathrm{N}$ ratio. Although we found no significant effect of $\mathrm{CO}_{2}$ on the soil $\mathrm{N}$ or $\mathrm{C} / \mathrm{N}$ ratio, we observed a decrease of

340 soil $\mathrm{N}$ and an increase in the soil $\mathrm{C} / \mathrm{N}$ ratio with increasing plant diversity. These kind of 341 effects have previously been reported (e.g. Oelmann,Wilcke, Temperton, Buchmann, Roscher et al 2007 and Roscher, Thein, Schmid \& Scherer Lorenzen 2008) and they are attributed to a better usage of the total resources, whether they be nitrogen or water (i.e. increased

344 complementarity). This mechanism contributes to the positive relationship between species

345 richness and above-ground biomass production and is often paralleled by a decrease in 
346 belowground available $\mathrm{N}$ due to increased efficiency in exploiting the available resource pool

347 but facilitating an increased accumulation of plant biomass as compared to low-diversity

348 communities (Roscher et al 2008). In support of this we found an increase of total plant

349 biomass with increasing diversity $\left(\mathrm{F}_{2,270}=6.6294, \mathrm{p}=0.002\right)$.

350 Earthworm presence is known to increase N cycling and availability (Scheu 2003;

351 Edwards 2004), however, in this study the presence of earthworms did not have any effect on

352 the availability of soil N. In our experiment this is presumably related to the low resource

353 (litter) inputs in our system, but we acknowledge that by measuring only changes in total soil

$354 \quad \mathrm{~N}$ we could have missed potential changes in available $\mathrm{N}$.

In conclusion, the findings of this experiment emphasize several interacting mechanisms by which elevated $\mathrm{CO}_{2}$ can modify the established relationship between plant diversity, earthworms and microorganisms. The results confirm our over-arching hypothesis that changes in belowground resource allocation, soil water and $\mathrm{N}$ availability mediated by

360 elevated $\mathrm{CO}_{2}$ alter the relationship between plant diversity and the functioning of the belowground compartment. Some of the observed interactions might be transient or magnified by the nature of this microcosm experiment. However, these results confirm the existence of several mechanisms which could determine the response and adaptation of essential soil functions such as decomposition, nutrient cycling, carbon storage, water

365 filtration and primary productivity to elevated $\mathrm{CO}_{2}$ at the ecosystem level. Such mechanisms and interactions need further investigation in order to understand and predict the interactive effects of climate change and diversity loss on ecosystem functioning and stability. 
370 We thank NERC for funding the placement student. We gratefully acknowledge Prof. Stefan

371 Scheu for allowing performing the microbial biomass analyses in his lab. We also thank Prof.

372 Mick Crawley for comments on the R statistical analysis, Dennis Wildman and Tom Sloan

373 for their invaluable technical support and Nico Eisenhauer and Alessandra Lagomarsino for

374 their comments on the manuscript.

\section{References}

377 Aarssen, L. (1997). High productivity in grassland ecosystems: effected by species diversity 378 or productive species? Oikos, $80,183-184$.

379 Anderson, J., \& Domsch, K. (1978). A physiological method for the quantitative

380 measurement of microbial biomass in soils. Soil Biol. Biochem, 10, 215-221.

381 Arnone III, J., \& Zaller, J. (1997). Activity of surface-casting earthworms in a calcareous

382 grassland under elevated atmospheric $\mathrm{CO}_{2}$. Oecologia, 111, 249-254.

383 Assessment, M., \& Reid, W. (2005). Ecosystems and human well-being: synthesis. Island

384 Press, Washington, DC.

385 Balvanera, P., Pfisterer, A., Buchmann, N., He, J., Nakashizuka, T., Raffaelli, D., \& Schmid,

386 B. (2006). Quantifying the evidence for biodiversity effects on ecosystem functioning and 387 services. Ecology Letters, 9, 1146-1156.

388 Bardgett, R. (2005). The biology of soil: a community and ecosystem approach. Oxford 389 University Press, USA.

390 Benton, T., Solan, M., Travis, J., \& Sait, S. (2007). Microcosm experiments can inform 391 global ecological problems. Trends in Ecology \& Evolution, 22, 516-521.

392 Blagodatskaya, E., Blagodatsky, S., Dorodnikov, M., \& Kuzyakov, Y. (2010). Elevated 393 atmospheric $\mathrm{CO} 2$ increases microbial growth rates in soil: results of three $\mathrm{CO}_{2}$ enrichment 394 experiments. Global Change Biology, 16, 836-848. 
395 Blouin, M., Lavelle, P., \& Laffray, D. (2007). Drought stress in rice (Oryza sativa L.) is 396 enhanced in the presence of the compacting earthworm Millsonia anomala. Environmental 397 and Experimental Botany, 60, 352-359.

398 Crawley, M. (2007). The R book. John Wiley \& Sons Inc.

399 De GraafF, MAvan GROENIGEN, K., Six, J., Hungate, B., \& van KESSEL, C. (2006).

400 Interactions between plant growth and soil nutrient cycling under elevated $\mathrm{CO}_{2}$ : a meta401 analysis. Global Change Biology, 12, 2077-2091.

402 Edwards, C., \& Bohlen, P. (1996). Biology and ecology of earthworms. Springer.

403 Edwards, W., Shipitalo, M., Owens, L., \& Norton, L. (1989). Water and nitrate movement in 404 earthworm burrows within long-term no-till cornfields. Journal of Soil and Water

405 Conservation, 44, 240.

406 Eisenhauer, N., Milcu, A., Sabais, A., Bessler, H., Weigelt, A., Engels, C., \& Scheu, S. 407 (2009). Plant community impacts on the structure of earthworm communities depend on 408 season and change with time. Soil Biology and Biochemistry, 41, 2430-2443.

409 Fischinger, S., Hristozkova, M., Mainassara, Z., \& Schulze, J. (2009). Elevated $\mathrm{CO}_{2}$

410 concentration around alfalfa nodules increases N2 fixation. Journal of experimental botany.

411 Hedlund, K., Santa Regina, I., Van der Putten, W., Lepš, J., Diaz, T., Korthals, G., Lavorel,

412 S., Brown, V., Gormsen, D., \& Mortimer, S. (2003). Plant species diversity, plant biomass

413 and responses of the soil community on abandoned land across Europe: idiosyncracy or

414 above-belowground time lags. Oikos, 103, 45-58.

415 Henwood, W. (1998). An overview of protected areas in the temperate grasslands biome.

416 Parks, 8, 3-8.

417 Huhta, V., Wright, D., \& Coleman, D. (1989). Characteristics of defaunated soil. I: A 418 comparison of three techniques applied to two different forest soils. Pedobiologia, 33, 417419426. 
420 Kanerva, T., Palojärvi, A., Rämö, K., \& Manninen, S. (2008). Changes in soil microbial 421 community structure under elevated tropospheric $\mathrm{O}_{3}$ and $\mathrm{CO}_{2}$. Soil Biology and Biochemistry,

422

423

424

425

426

427

428

430

431

432

433

434

435

436

437

438

439

440

441

442

40, 2502-2510.

Kardol, P., Cregger, M., Campany, C., \& Classen, A. (2010). Soil ecosystem functioning under climate change: plant species and community effects. Ecology, 91, 767-781.

Lavelle, P. (1988). Earthworm activities and the soil system. Biology and Fertility of Soils, 6, 237-251.

Meehan, T., Crossley, M., \& Lindroth, R. Impacts of elevated $\mathrm{CO}_{2}$ and $\mathrm{O}_{3}$ on aspen leaf litter chemistry and earthworm and springtail productivity. Soil Biology and Biochemistry.

Milcu, A., Partsch, S., Langel, R., \& Scheu, S. (2006). The response of decomposers (earthworms, springtails and microorganisms) to variations in species and functional group diversity of plants. Oikos, 112,513 .

Milcu, A., Partsch, S., Scherber, C., Weisser, W.W., \& Scheu, S. (2008). Earthworms and legumes control litter decomposition in a plant diversity gradient. Ecology, 89, 1872-1882. Morgan, J., Lecain, D., Mosier, A., \& Milchunas, D. (2001). Elevated $\mathrm{CO}_{2}$ enhances water relations and productivity and affects gas exchange in C3 and C4 grasses of the Colorado shortgrass steppe. Global Change Biology, 7, 451-466.

Nelson, J., Morgan, J., LeCain, D., Mosier, A., Milchunas, D., \& Parton, B. (2004). Elevated CO 2 increases soil moisture and enhances plant water relations in a long-term field study in semi-arid shortgrass steppe of Colorado. Plant and Soil, 259, 169-179.

Niklaus, P., Alphei, J., Kampichler, C., Kandeler, E., Körner, C., Tscherko, D., \& Wohlfender, M. (2007). Interactive effects of plant species diversity and elevated $\mathrm{CO}_{2}$ on soil biota and nutrient cycling. Ecology, 88, 3153-3163. 
443 Oelmann, Y., Temperton, Y., Buchmann, V., Roscher, N., Schumacher, C., Schulze, J.,

444 Weisser, E., \& Wilcke, W. (2007). Nitrogen and phosphorus budgets in experimental

445 grasslands of variable diversity.

446 O'Neill, E. (1994). Responses of soil biota to elevated atmospheric carbon dioxide. Plant and

447 Soil, 165, 55-65.

448 Reich, P. (2009). Elevated $\mathrm{CO}_{2}$ reduces losses of plant diversity caused by nitrogen

449 deposition. Science, 326, 1399.

450 Reich, P., Knops, J., Tilman, D., Craine, J., Ellsworth, D., Tjoelker, M., Lee, T., Wedin, D.,

451 Naeem, S., \& Bahauddin, D. (2001). Plant diversity enhances ecosystem responses to

452 elevated CO2 and nitrogen deposition. Nature, 410, 809-810.

453 Roscher, C., Temperton, V., Scherer-Lorenzen, M., Schmitz, M., Schumacher, J., Schmid, B., 454 Buchmann, N., Weisser, W., \& Schulze, E. (2005). Overyielding in experimental grassland 455 communities-irrespective of species pool or spatial scale. Ecology Letters, 8, 419-429.

456 Roscher, C., Thein, S., Schmid, B., \& Scherer Lorenzen, M. (2008). Complementary nitrogen

457 use among potentially dominant species in a biodiversity experiment varies between two

458 years. Journal of Ecology, 96, 477-488.

459 Scheu, S. (1992). Automated measurement of the respiratoy response of soil

460 microcompartments: active microbial biomass in earthworm feaces. Soil Biology and

461 Biochemistry., 24, 1113-1118.

462 Scheu, S. (2003). Effects of earthworms on plant growth: patterns and perspectives:: The 7th

463 international symposium on earthworm ecology Cardiff- Wales. 2002. Pedobiologia, 47, $464846-856$.

465 Schulze, J., \& Merbach, W. (2008). Nitrogen rhizodeposition of young wheat plants under 466 elevated CO 2 and drought stress. Biology and Fertility of Soils, 44, 417-423. 
467 Sheehan, C., Kirwan, L., Connolly, J., \& Bolger, T. (2008). The effects of earthworm 468 functional diversity on microbial biomass and the microbial community level physiological 469 profile of soils. European Journal of Soil Biology, 44, 65-70.

470 Solomon, S., Qin, D., Manning, M., Chen, Z., Marquis, M., Averyt, K., Tignor, M., \& Miller, 471 H. (2007). Climate change 2007: the physical science basis. University Press.

472 Spehn, E., Joshi, J., Schmid, B., Alphei, J., \& Körner, C. (2000). Plant diversity effects on 473 soil heterotrophic activity in experimental grassland ecosystems. Plant and Soil, 224, $217-$ 474230.

475 Swift, M., Heal, O., \& Anderson, J. (1979). Decomposition in terrestrial ecosystems. Univ of 476 California Pr.

477 Tilman, D., Reich, P.B., \& Knops, J.M.H. (2006). Biodiversity and ecosystem stability in a 478 decade-long grassland experiment. Nature, 441, 629-632.

479 Tricker, P., Trewin, H., Kull, O., Clarkson, G., Eensalu, E., Tallis, M., Colella, A., Doncaster, 480 C., Sabatti, M., \& Taylor, G. (2005). Stomatal conductance and not stomatal density 481 determines the long-term reduction in leaf transpiration of poplar in elevated $\mathrm{CO}_{2}$. Oecologia, $482143,652-660$.

483 Wardle, D. (2002). Communities and ecosystems: linking the aboveground and belowground 484 components. Princeton Univ Pr.

485 Wardle, D., Bonner, K., Barker, G., Yeates, G., Nicholson, K., Bardgett, R., Watson, R., \& 486 Ghani, A. (1999). Plant removals in perennial grassland: vegetation dynamics, decomposers, 487 soil biodiversity, and ecosystem properties. Ecological Monographs, 69, 535-568.

488 Wullschleger, S., Tschaplinski, T., \& Norby, R. (2002). Plant water relations at elevated 489 CO2-implications for water limited environments. Plant, Cell \& Environment, 25, 319-331. 
490 Yeates, G., Tate, K., \& Newton, P. (1997). Response of the fauna of a grassland soil to

491 doubling of atmospheric carbon dioxide concentration. Biology and Fertility of Soils, 25,

$492 \quad 307-315$.

493 Zak, D., Pregitzer, K., King, J., \& Holmes, W. (2000). Elevated atmospheric $\mathrm{CO}_{2}$, fine roots

494 and the response of soil microorganisms: a review and hypothesis. New Phytologist, 147,

$495 \quad 201-222$.

496 Zaller, J., \& Arnone III, J. (1999). Earthworm and soil moisture effects on the productivity

497 and structure of grassland communities. Soil Biology and Biochemistry, 31, 517-523.

498 Zaller, J., \& Arnone III, J. (1999). Interactions between plant species and earthworm casts in 499 a calcareous grassland under elevated $\mathrm{CO}_{2}$. Ecology, 80, 873-881.

500 Zaller, J., \& Arnone, J. (1999). Earthworm responses to plant species' loss and elevated $\mathrm{CO}_{2}$

501 in calcareous grassland. Plant and Soil, 208, 1-8. 
Table 1. Output table of mix-effects models for the effect of $\mathrm{CO}_{2}$ treatment $\left(\mathrm{CO}_{2}\right)$, earthworm presence (EW), plant species richness (SR) and their interactions on the belowground response variables. Excluded effects refer to the treatment factors which have been removed from the model in order to achieve minimum adequate models (Crawley 2007).

\begin{tabular}{|c|c|c|c|c|c|c|c|c|c|c|c|c|c|c|c|}
\hline & \multicolumn{15}{|c|}{ Belowground measurements } \\
\hline & \multicolumn{3}{|c|}{ Earthworm biomass } & \multicolumn{3}{|c|}{ Soil moisture } & \multicolumn{3}{|c|}{ Soil N } & \multicolumn{3}{|c|}{ Soil C to $\mathrm{N}$ ratio } & \multicolumn{3}{|c|}{ Microbial biomass } \\
\hline & df & $F$ & $P$ & df & $F$ & $P$ & $\mathrm{df}$ & $F$ & $P$ & $\mathrm{df}$ & $F$ & $P$ & df & $F$ & $P$ \\
\hline $\mathrm{CO}_{2}$ & 1,6 & 0.32 & 0.591 & 1,6 & 11.12 & 0.015 & 1,6 & 0.1 & 0.947 & 1,6 & 0.48 & 0.514 & 1,6 & 4.69 & 0.073 \\
\hline EW & n.a & n.a & n.a & 1,273 & 108.7 & $<.001$ & 1,253 & 1.1 & 0.284 & 1,256 & 2.75 & 0.098 & 1,256 & 0.9 & 0.342 \\
\hline SR & 2,101 & 1.61 & 0.205 & 2,273 & 7.9 & $<.001$ & 2,253 & 0.161 & 0.021 & 2,256 & 3.54 & $\mathbf{0 . 0 3 0}$ & 2,256 & 3.1 & 0.047 \\
\hline $\mathrm{CO}_{2} \times \mathrm{EW}$ & excl. & excl. & excl. & 1,273 & 9.7 & 0.002 & 1,253 & 0.1 & 0.777 & excl. & excl. & excl. & 1,256 & 0.1 & 0.969 \\
\hline
\end{tabular}




\section{Figure legends}

Figure 1. Two-way interaction effects of plant species richness (SR) and atmospheric $\mathrm{CO}_{2}$ treatment on earthworm mass loss (A), effects of $\mathrm{SR}$ on soil $\mathrm{C} / \mathrm{N}$ ratio (B) and twoway interaction effects of SR and earthworm presence on soil moisture (C). Error bars represent \pm SE

Figure 2. Three-way interaction effects between plant species richness (SR), atmopsperic $\mathrm{CO}_{2}$ and earthworm presence on the carbon (glucose) induced microbial biomass (Cmic). Error bars represent $\pm \mathrm{SE}$ 


\section{Figure 1}
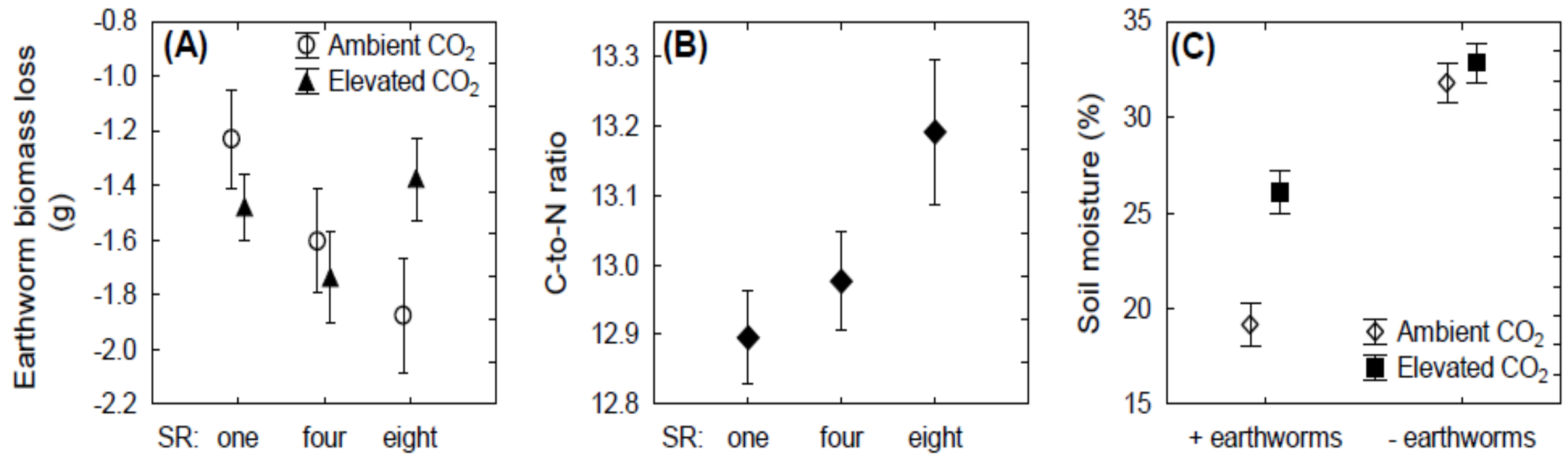


\section{Figure 2}
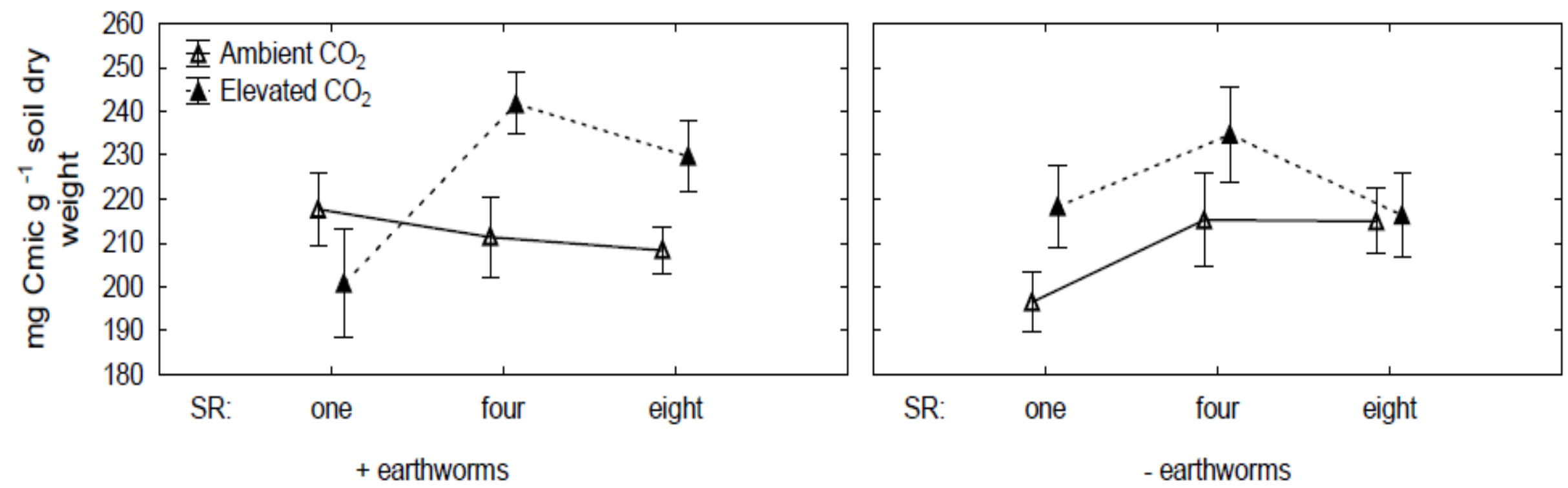
Appendix A. Experimental design layout of the 18 different species mixtures. Grasses are shown in yellow, herbs in green and legumes in dark green.

\begin{tabular}{|c|c|c|c|c|c|c|c|c|c|}
\hline $\mathrm{Nr}$ & Diversity level & \multicolumn{8}{|c|}{ Plant Species in Microcosm } \\
\hline 1 & Monoculture & \multicolumn{2}{|c|}{\begin{tabular}{ll|l} 
Bromus hordeaceus & \\
\cline { 1 - 1 } &
\end{tabular}} & & & & \multirow[b]{2}{*}{ Grass } & & \\
\hline 2 & Monoculture & & & & & & & \\
\hline 3 & Monoculture & \multicolumn{2}{|c|}{ Achillea millefolium } & & & & Herb & & \\
\hline 4 & Monoculture & \multicolumn{2}{|c|}{ Dipsacus fullonum } & & & & Legume & & \\
\hline 5 & Monoculture & \multicolumn{4}{|c|}{ Trifolium repens } & & & & \\
\hline 6 & Monoculture & \multicolumn{4}{|c|}{ Vicia cracca } & & & & \\
\hline 7 & 4-species-mixture & $\begin{array}{l}\text { Holcus } \\
\text { lanatus }\end{array}$ & $\begin{array}{l}\text { Lolium } \\
\text { perenne }\end{array}$ & $\begin{array}{l}\text { Vulpia } \\
\text { bromoides }\end{array}$ & $\begin{array}{l}\text { Festuca } \\
\text { pratensis }\end{array}$ & & & & \\
\hline 8 & 4-species-mixture & $\begin{array}{l}\text { Taraxacum } \\
\text { officinale }\end{array}$ & $\begin{array}{l}\text { Rumex } \\
\text { acetosella }\end{array}$ & $\begin{array}{l}\text { Dipsacus } \\
\text { fullonum }\end{array}$ & $\begin{array}{l}\text { Daucus } \\
\text { carota }\end{array}$ & & & & \\
\hline 9 & 4-species-mixture & $\begin{array}{l}\text { Trifolium } \\
\text { dubium }\end{array}$ & $\begin{array}{l}\text { Trifolium } \\
\text { pratense }\end{array}$ & $\begin{array}{l}\text { Medicago } \\
\text { lupulina }\end{array}$ & Vicia sativa & & & & \\
\hline 10 & 4-species-mixture & $\begin{array}{l}\text { Bromus } \\
\text { hordeaceus }\end{array}$ & $\begin{array}{l}\text { Lolium } \\
\text { perene }\end{array}$ & $\begin{array}{l}\text { Leontodon } \\
\text { hispidus }\end{array}$ & Vicia sativa & & & & \\
\hline 11 & 4-species-mixture & $\begin{array}{l}\text { Bromus } \\
\text { sterilis }\end{array}$ & $\begin{array}{l}\text { Plantago } \\
\text { lanceolata }\end{array}$ & $\begin{array}{l}\text { Taraxacum } \\
\text { officinale }\end{array}$ & $\begin{array}{l}\text { Lotus } \\
\text { corniculatus } \\
\end{array}$ & & & & \\
\hline 12 & 4-species-mixture & $\begin{array}{l}\text { Alopecurus } \\
\text { pratensis }\end{array}$ & $\begin{array}{l}\text { Myosotis } \\
\text { arvensis }\end{array}$ & $\begin{array}{l}\text { Trifolium } \\
\text { pratense }\end{array}$ & $\begin{array}{l}\text { Lathyrus } \\
\text { tuberosus }\end{array}$ & & & & \\
\hline 13 & 8-species-mixture & $\begin{array}{l}\text { Holcus } \\
\text { lanatus }\end{array}$ & $\begin{array}{l}\text { Anthoxanthu } \\
\text { m odoratum }\end{array}$ & $\begin{array}{l}\text { Festuca } \\
\text { pratensis }\end{array}$ & $\begin{array}{l}\text { Alopecurus } \\
\text { pratensis }\end{array}$ & $\begin{array}{l}\text { Agrostis } \\
\text { capillaris }\end{array}$ & $\begin{array}{l}\text { Festuca } \\
\text { rubra }\end{array}$ & $\begin{array}{l}\text { Bromus } \\
\text { sterilis }\end{array}$ & Роа аппиа \\
\hline 14 & 8-species-mixture & $\begin{array}{l}\text { Galium } \\
\text { mollugo }\end{array}$ & $\begin{array}{l}\text { Plantago } \\
\text { lanceolata }\end{array}$ & $\begin{array}{l}\text { Matricaria } \\
\text { recutita }\end{array}$ & $\begin{array}{l}\text { Daucus } \\
\text { carota }\end{array}$ & $\begin{array}{l}\text { Prunella } \\
\text { vulgaris } \\
\end{array}$ & $\begin{array}{l}\text { Leontodon } \\
\text { hispidus }\end{array}$ & $\begin{array}{l}\text { Myosotis } \\
\text { arvensis }\end{array}$ & Rumex acetosella \\
\hline 15 & 8-species-mixture & $\begin{array}{l}\text { Trifolium } \\
\text { dubium }\end{array}$ & Vicia sativa & $\begin{array}{l}\text { Lathyrus } \\
\text { pratensis }\end{array}$ & Vicia cracca & $\begin{array}{l}\text { Lotus } \\
\text { corniculatus } \\
\end{array}$ & $\begin{array}{l}\text { Medicago } \\
\text { sativa }\end{array}$ & $\begin{array}{l}\text { Trifolium } \\
\text { medium }\end{array}$ & $\begin{array}{l}\text { Medicago } \\
\text { lupulina } \\
\end{array}$ \\
\hline 16 & 8-species-mixture & $\begin{array}{l}\text { Elytrigia } \\
\text { repens }\end{array}$ & $\begin{array}{l}\text { Anthoxanthu } \\
\text { m odoratum }\end{array}$ & $\begin{array}{l}\text { Festuca } \\
\text { rubra }\end{array}$ & $\begin{array}{l}\text { Plantago } \\
\text { lanceolata }\end{array}$ & $\begin{array}{l}\text { Prunella } \\
\text { vulgaris } \\
\end{array}$ & $\begin{array}{l}\text { Dipsacus } \\
\text { fullonum }\end{array}$ & $\begin{array}{l}\text { Medicago } \\
\text { lupulina }\end{array}$ & $\begin{array}{l}\text { Lotus } \\
\text { corniculatus }\end{array}$ \\
\hline 17 & 8-species-mixture & $\begin{array}{l}\text { Lolium } \\
\text { perene }\end{array}$ & $\begin{array}{l}\text { Bromus } \\
\text { sterilis } \\
\end{array}$ & $\begin{array}{l}\text { Achillea } \\
\text { millefolium }\end{array}$ & $\begin{array}{l}\text { Matricaria } \\
\text { recutita }\end{array}$ & $\begin{array}{l}\text { Leucanthem } \\
\text { um vulgare }\end{array}$ & Vicia sativa & $\begin{array}{l}\text { Trifolium } \\
\text { medium }\end{array}$ & Medicago sativa \\
\hline 18 & 8-species-mixture & $\begin{array}{l}\text { Dactylis } \\
\text { glomerata }\end{array}$ & $\begin{array}{l}\text { Holcus } \\
\text { lanatus }\end{array}$ & $\begin{array}{l}\text { Festuca } \\
\text { pratensis }\end{array}$ & $\begin{array}{l}\text { Leucanthem } \\
\text { um vulgare }\end{array}$ & $\begin{array}{l}\text { Achillea } \\
\text { millefolium }\end{array}$ & $\begin{array}{l}\text { Trifolium } \\
\text { dubium }\end{array}$ & Vicia cracca & $\begin{array}{l}\text { Lathyrus } \\
\text { tuberosus }\end{array}$ \\
\hline
\end{tabular}

